\title{
Field Resistance to Potato Stem Colonization by the Black Dot Pathogen Colletotrichum coccodes
}

\author{
Nadav Nitzan, Vegetable Forage Crops and Research Unit, USDA-ARS, Prosser, WA 99350; Marc A. Evans, De- \\ partment of Statistics, Washington State University, Pullman 99164; Tom F. Cummings and Dennis A. Johnson, \\ Department of Plant Pathology, Washington State University, Pullman 99164; Dallas L. Batchelor, Lamb-Weston, \\ Pasco, WA 99301; Chris Olsen, L.J. Olsen, Inc., Othello, WA 99344; Kathleen G. Haynes, Plant Sciences Institute, \\ Genetic Improvement of Fruits and Vegetables Laboratory, USDA-ARS, Beltsville, MD; and Charles R. Brown, \\ Vegetable Forage Crops and Research Unit, USDA-ARS, Prosser, WA 99350
}

\begin{abstract}
Nitzan, N., Evans, M. A., Cummings, T. F., Johnson, D. A., Batchelor, D. L., Olsen, C., Haynes, K. G., and Brown, C. R. 2009. Field resistance to potato stem colonization by the black dot pathogen Colletotrichum coccodes. Plant Dis. 93:1116-1122.

Potato (Solanum tuberosum) germplasm was tested for resistance to stem colonization by the black dot pathogen Colletotrichum coccodes. Forty-six potato selections were tested in three field trials from 2006 to 2008 . Resistance was determined by comparing disease severity on aboveground stems to the mean disease severity of the industry standards Russet Burbank, Ranger Russet, and Umatilla Russet. The potato selections were also tested for genotype*environment interaction to determine their genetic stability. Heritability of resistance was calculated to be 0.13 with confidence intervals between 0.00 and 0.68 . The selections A0012-5, PA95B2-4, PA98NM38-1, and PO94A009-7 had less black dot than the standards in all years, and also demonstrated genetic stability. These selections also possess resistance to the root galling stage of the powdery scab pathogen Spongospora subterranea f. sp. subterranea. PA95B2-4, PA98NM38-1, and PO94009-7 were derived from an introgression program to incorporate resistance to the Columbia root-knot nematode Meloidogyne chitwoodi from the Mexican wild species Solanum bulbocastanum, and also have the commercial cultivar Summit Russet in their ancestry. These selections are promising steps toward sustainable management of black dot and powdery scab and will be further tested and used for breeding purposes.
\end{abstract}

Potato black dot, caused by the fungus Colletotrichum coccodes (Wallr.) S. Hughes (8), is of economic concern in several major potato (Solanum tuberosum) producing regions in North America (5,1517,20,28,32,35). The disease can decrease tuber yield weight from 16 to $30 \%$ due to early death of the crop $(3,12,18,31,36$, $45,46)$, and can reduce tuber quality due to gray-brown blemishes on the epidermis of white and red potatoes $(24,44,46)$. C. coccodes also has been associated with the "bumpy tuber syndrome", a postharvest storage disease in which necrotic bumps develop under the potato epidermis (32).

Potato tubers may be infected with $C$. coccodes externally by sclerotia, internally in the vascular tissues near the stolon end by mycelial hyphae (14), or in combinations $(24,45,46)$. Infected potato tubers are

Corresponding author: Charles R. Brown

E-mail: chuck.brown@ars.usda.gov

Accepted for publication 15 June 2009.

doi:10.1094/PDIS-93-11-1116

This article is in the public domain and not copyrightable. It may be freely reprinted with customary crediting of the source. The American Phytopathological Society, 2009. the main source for disseminating the pathogen. When such tubers are planted to virgin soils, they infest the soils and the fungus becomes soilborne (46). Soil and tubers are the sources of fungal inoculum that initiate the disease, and the soilborne inoculum is the more aggressive of the two $(10-12,23,28,29,40,41)$. Infection of the plants occurs on the belowground organs relatively early in the season without evident symptoms of chlorosis or necrosis on the foliage $(2,19)$. As plants enter the tuber bulking stage (growth stage 4), and the foliage starts to senesce (27), the pathogen spreads into the aboveground stems and colonizes the plant (31). At the end of the season, sclerotia become visually evident on roots, stolons, and stems $(28,29,31$, 32,34,36).

Potatoes vary in susceptibility to black dot as was demonstrated with the cultivars Cara, Pentland Crown, and Romano that were recorded to be less susceptible to tuber blemishes than Desiree, Maris Piper, and Maris Peer (39). Tsror et al. (45) recorded variation in yield, stem colonization, and tuber infection among the four potato cultivars Alpha, Cara, Nicola, and Desiree. However, to date, resistance to black dot, in which fungal development is restricted completely or to some degree, has not been reported in potato germplasm.

The present study tested the hypothesis that resistance to potato black dot is present in potato germplasm. The objectives of the study were (i) to identify resistance to black dot in potato, and (ii) to evaluate stem cuttings as a screening technique. This study was part of the Northwest TriState Potato Breeding Program, which is a collaborative effort of the USDA-ARS, Washington State University, Oregon State University, the University of Idaho, the potato commission of each state, and industry representatives. The purpose of this collaborative effort is to develop potato cultivars with agronomic and horticultural characteristics, and resistance to pests and pathogens, which would be suitable for the potato industry in the Northwest United States.

\section{MATERIALS AND METHODS}

The majority of the germplasm (potato selections) in this study were chosen because in previous field and greenhouse trials they demonstrated resistance to potato powdery scab, caused by Spongospora subterranea (30), and/or to the Columbia root-knot nematode Meloidogyne chitwoodi (6). Some of the potato selections tested in this study were chosen randomly from the Tri-State Breeding Program. The industry standard potato cultivars Russet Burbank, Ranger Russet, and Umatilla Russet were included in all three trials for comparison.

The field trials were carried out from 2006 to 2008 in a commercial potato farm located near Moses Lake, WA. All the fields in this farm had a history of severe black dot. Each year, the trials were carried out in a different field on the farm. The potato selections were obtained as seedtubers from the Central Oregon Experiment Station of Oregon State University, located near Powell Butte, and from the USDA-ARS Potato Research Unit, located near Aberdeen, ID. The tubers were cut into pieces of $50 \mathrm{~g}$ on average, and were treated with Mancozeb (TOPS®MZ; Gustafson LCC, Plano, TX) by adding 5 $\mathrm{ml}$ of the fungicide to 20 tuber seed pieces in a large paper bag $(31 \times 18 \times 58 \mathrm{~cm})$ and 
shaking well until the tuber seed pieces were fully covered with the fungicide. The tuber seed pieces were maintained in the paper bags at $5^{\circ} \mathrm{C}$ until used.

The trials were arranged in a randomized complete block design with a one-way treatment structure (potato selection), with three replicated blocks in 2006 and four replicated blocks in 2007 and 2008. The experimental plots for a potato selection were a single row measuring $86 \mathrm{~cm}$ wide by $114 \mathrm{~cm}$ long. Five seed tuber pieces were planted to each plot (5 hill plot) at spacing of $23 \mathrm{~cm}$. The trials were planted each year during the first week of April. Stems for evaluation of black dot severity were sampled in the first week of September each year corresponding with the potato growing season and with potato plants' senescence.

The severity of black dot in the field was quantified on the aboveground stem by detection on culture medium, and was expressed as disease severity index (DSI). In 2006, a total of 3 to 9 stems were assessed for each potato selection; and in 2007 and 2008, a total of 12 stems were assessed for each potato selection. The stems were washed with running tap water to remove soil deposits, surface-sterilized for $10 \mathrm{~min}$ in $10 \%$ bleach, washed again, and their surface was let dry at room temperature before cutting. Then stem segments of approximately $5 \mathrm{~mm}$ were removed aseptically. In 2006, stem segments were removed from 2 and $6 \mathrm{~cm}$ aboveground; in 2007 from 2, 6, 10, and $14 \mathrm{~cm}$ aboveground; and in 2008 from 2, 6, and $10 \mathrm{~cm}$ aboveground. The stem segments were placed in 9-mm petri plates onto a modified potato dextrose agar composed of $1 \mathrm{~g} /$ liter PDA, $10 \mathrm{~g} /$ liter Bacto agar, 0.01 $\mathrm{g} / \mathrm{liter}$ streptomycin sulfate, and $5 \mathrm{ml} / \mathrm{liter}$ 95\% ethanol that was added to the media when it cooled down to approximately $30^{\circ} \mathrm{C}$. The stem segments were incubated at $25^{\circ} \mathrm{C}$ in the dark. Fungal growth was visible on the stem segments and on the growth media 10 days later.

Using a dissecting microscope, the presence or absence of $C$. coccodes sclerotia on the stem segment and/or the growth medium was visually verified. The colonization outcome was recorded as " 1 " for a colonized segment, and " 0 " for a noncolonized segment. Then the disease severity index (DSI) on the aboveground stem was calculated by multiplying the colonization outcome ( 0 or 1$)$ by the height aboveground from which the segment was removed $(2,6,10$, or $14 \mathrm{~cm})$. The multiplications for each stem were totaled. Then, the total was divided by the highest value it could obtain assuming all segments were infected, which were 8, 32, and 18 in 2006, 2007, and 2008, respectively. Doing so, the DSI was standardized and converted into percentage $(\%)$. Hence, in $2006, \operatorname{DSI}(\%)=$ $\{[2 *(0$ or 1$)+6 *(0$ or 1$)] / 8\}$; in 2007 , $\operatorname{DSI}(\%)=\{[2 *(0$ or 1$)+6 *(0$ or 1$)+$
$10 *(0$ or 1$)+14 *(0$ or 1$)] / 32\}$; and in $2008, \operatorname{DSI}(\%)=\{[2 *(0$ or 1$)+6 *(0$ or 1$)$ $+10 *(0$ or 1$)] / 18\}$.

DSI of potato selections that were in common to all 3 years was analyzed by year and across years using the mixed models procedure in SAS (Version 9.1, SAS Institute, Cary, NC). To determine black dot resistance, each potato selection was individually compared to the mean DSI of the three industry standard cultivars (Russet Burbank, Ranger Russet, and Umatilla Russet) using "DSI estimate" statements. The DSI estimate statements compared the adjusted mean difference in DSI between the chosen potato selection and the mean DSI of the industry standard cultivars. A negative DSI estimate value indicated that the potato selection had less black dot than the industry standards from the standpoint of the DSI. The more negative the value, the lower the amount of disease. A positive estimate value indicated that the potato selection had more black dot than the industry standards. Potato selections with a negative estimated value that was significantly $(P<0.05)$ lower than the mean DSI of the industry standards were regarded as resistant to black dot. Potato selections with a negative estimate value that was reasonably $(0.05 \leq P \leq$ $0.1)$ lower than the mean DSI of the standard cultivars were considered moderately resistant to black dot. The potato selections demonstrating a positive DSI estimate, and the potato selection demonstrating a negative DSI estimate that was not significantly or reasonably lower than the mean DSI of the industry standards were recorded as susceptible. To determine the consistency of DSI for a given potato selection, the average DSI levels of each year were compared in the mixed models procedures using the differences of least squares means for the year*potato selection effect.

Error variances for the analyses by year were homogeneous, so data were combined over years for the potato selections in common to all 3 years to investigate the genotypic stability of each potato selection. The genotype*environment interaction $(\mathrm{G} \times \mathrm{E})$ was partitioned into stability variance components $\left(\sigma_{i}^{2}\right)$ assignable to each genotype (43) using PROC IML in SAS (21). An environmental index for each environment was calculated by subtracting the grand mean over all environments from the mean for each environment. Heterogeneity due to this index was removed from the genotype*environment interaction, and the remainder was partitioned into $s_{i}^{2}$ assignable to each potato selection, and constitutes variance not explainable by genotype or environment. Mean squares from this analysis were used to estimate the genotype, environment, and genotype*environment components of variance. Broad-sense heritability was estimated as the ratio of the variance component of genotypes over total phenotypic variance, $H=\sigma_{\mathrm{G}}^{2} /\left(\left(\sigma_{\text {error }}^{2} / 10\right)+\left(\sigma_{\mathrm{G} \times \mathrm{E}}^{2} / 5\right)+\right.$ $\sigma_{G}^{2}$ ). Knapp et al. (22) determined the exact confidence interval for $H$. The upper confidence interval is $1-\left[\left(\mathrm{MS}_{1} / \mathrm{MS}_{2}\right) F_{(1-}\right.$ $\alpha / 2: \mathrm{df2} 2 \mathrm{df1})]^{-1}$, while the lower confidence interval is $1-\left[\left(\mathrm{MS}_{1} / \mathrm{MS}_{2}\right) F_{(\alpha / 2: \mathrm{df} 2, \mathrm{df} 1)}\right]^{-1}$, where $\mathrm{MS}_{1}=$ mean squares for genotype and $\mathrm{MS}_{2}=$ mean squares for genotype*environment.

Correlation between DSI consistency and genetic stability was tested with the Kendall Tau b ranking correlation analysis in SAS (47).

\section{RESULTS}

Forty-six potato selections (experimental clones and commercial cultivars) were tested between 2006 and 2008 in order to identify selections with resistance to black dot. Thirty-six potato selections were tested in 2006 (Fig. 1), 24 in 2007 (Fig. 2), and 26 in 2008 (Fig. 3). Potato selections with greater amounts of black dot than the industry standards in two consecutive trials were usually discarded. A total of 17 potato selections were tested all 3 years and were in common to all three trials.

The industry standard cultivars Russet Burbank, Ranger Russet, and Umatilla Russet had similar $(P>0.05)$ levels of disease severity index on aboveground stems (DSI) in 2006 (Table 1). In 2007, the DSI of Russet Burbank was significantly greater $(P<0.05)$ than the DSI of Ranger Russet, but not greater than the DSI of Umatilla Russet. In 2008, the DSI of Umatilla Russet was significantly greater $(P<$ $0.05)$ than the DSI of Ranger Russet, and moderately greater $(P=0.055)$ than the DSI of Russet Burbank.

DSI data analysis of the 17 potato selections in common in all three trials indicated a significant $(P<0.0001)$ potato selection*year interaction. This interaction was manifested by inconsistent DSI levels in some potato selections over the 3 years of the study (Table 2). The analysis for genetic stability indicated an interaction between potato selection and environment $(\mathrm{G} \times \mathrm{E})$ in relation to black dot severity, and the presence of genetically unstable potato selection even after removing environmental effects. The heritability of resistance to black dot was computed to be 0.13 , with a $95 \%$ confidence interval of 0.00 to 0.68 . DSI inconsistency and genetic stability were significantly correlated $\left(P=0.0095, R^{2}=0.65\right)$. The potato selections A0012-5, PA95B2-4, PA98N5-2, PA98NM38-1, PO94A009-7, PA99N82-4, and Umatilla Russet were recorded to be genetically stable to black dot, and with consistent DSI levels over the 3 years of the study (Table 2).

Table 3 summarized the DSI estimate comparisons between each of the 17 potato selections in common in all 3 years and the industry standards. In 2006, 13 potato selections had a negative DSI estimate value, indicating that they had less disease than the standards. Among those 13 potato 
selections, 11 were significantly $(P<0.05)$ resistant to black dot. In 2007,8 potato selections had a negative DSI estimate value, and among those only 1 was significantly resistant to black dot. In 2008, 4 potato selections had a negative DSI estimate value, and among those 2 were mod- erately resistant $(0.05 \leq P \leq 0.1)$ to black dot. Across all years, the five potato selections A0012-5, PA95B2-4, PA98NM38-1, PO94A009-7, and POR00HG5-1 were resistant to black dot, and the selections A00681-7 and Summit Russet were moderately resistant. Among these selections,
A0012-5, PA95B2-4, PA98NM38-1, and PO94A009-7 also were genetically stable and had consistent DSI (Table 2).

\section{DISCUSSION}

The present study tested the hypothesis that resistance to potato black dot was

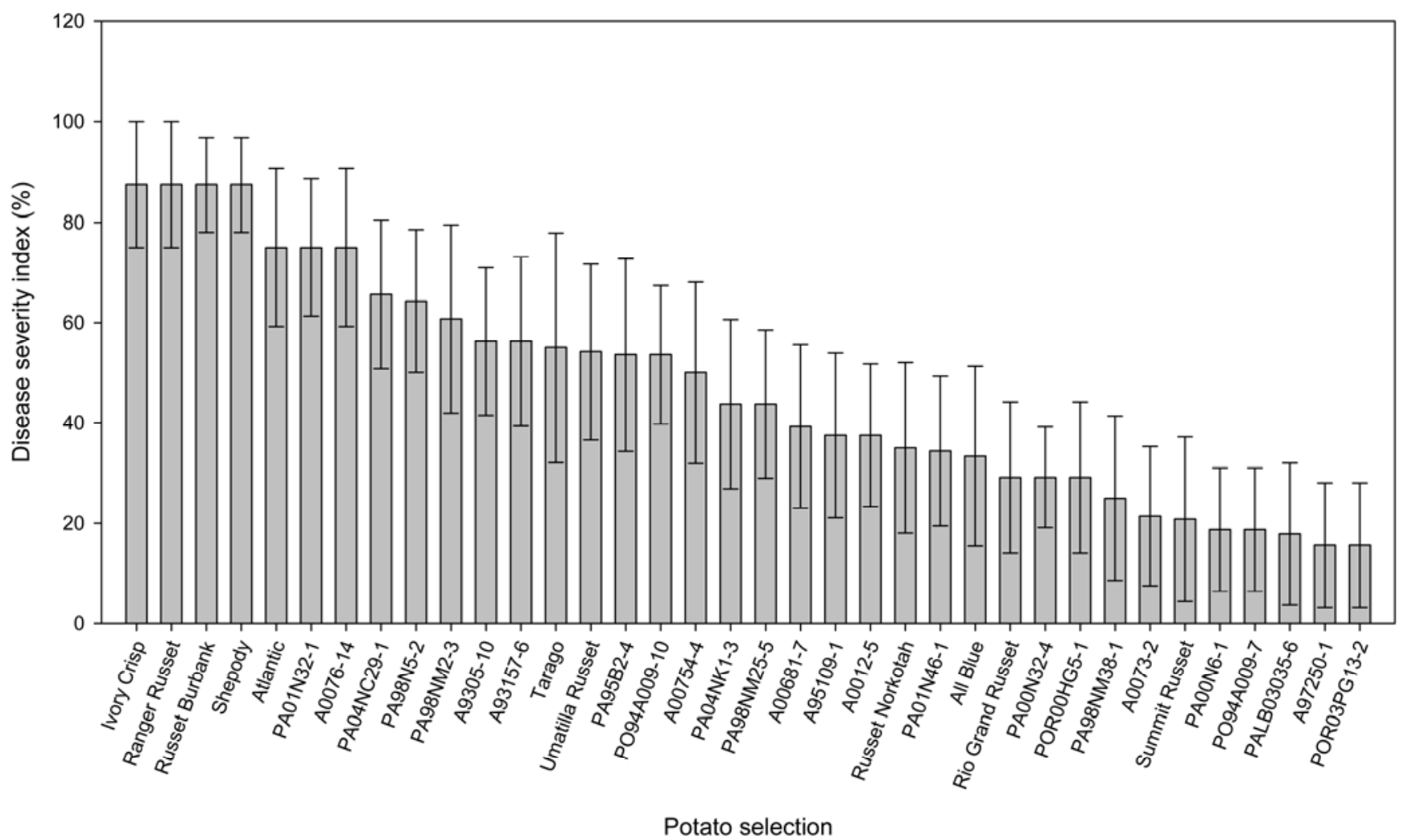

Fig. 1. Disease severity index (DSI) on aboveground stem of potato germplasm tested for black dot resistance in 2006 in a commercial potato field near Moses Lake, WA. Error bars represent the standard error of the mean.

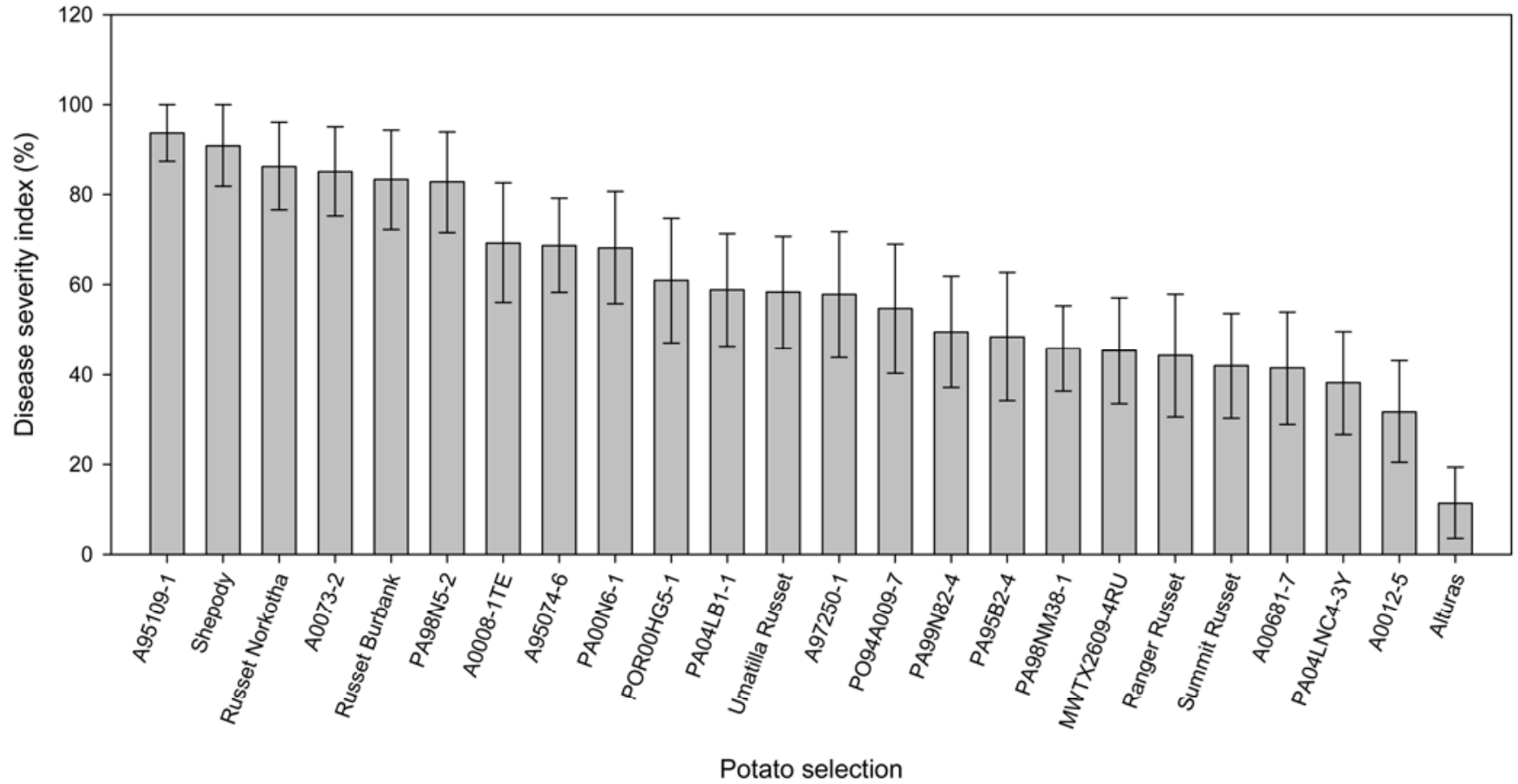

Fig. 2. Disease severity index (DSI) on aboveground stem of potato germplasm tested for black dot resistance in 2007 in a commercial potato field near Moses Lake, WA. Error bars represent the standard error of the mean. 
present in potato germplasm. The objectives of this study were (i) to identify potato germplasm with resistance to stem colonization by $C$. coccodes, and (ii) to evaluate stem cuttings as a screening technique. Agrios (1) defined disease resistance as the ability of an organism to exclude or overcome, completely or in some degree, the effect of a pathogen or other damaging factor. In previous studies $(31,36)$, C. coccodes was recorded spreading upward in the stem from the inoculation court or the roots toward the plant's apex. With this knowledge, and based on the definition by Agrios (1), we hypothesized that potato selections that were resistance to stem colonization by $C$. coccodes would restrict the fungus from spreading upward in the stem. Five potato selections, A0012-5, PA95B2-4, PA98NM38-1, PO94A009-7, and POR00HG5-1, demonstrated less stem colonization over 3 years than a set of three industry standard cultivars. Therefore, the results of this study supported the tested hypothesis, indicating the presence of resistance to stem colonization by the potato black dot fungus in potato germplasm.

This was the first reported study where potato germplasm were tested for resistance to black dot. Therefore, considerations had to be made regarding the germplasm to be screened and the screening method. The majority of the germplasm in this study were chosen because they had demonstrated resistance to two important pests in the Pacific Northwest region: (i) the potato powdery scab obligate protozoan parasite Spongospora subterranea (30), and (ii) the Columbia root-knot nematode Meloidogyne chitwoodi (6).
However, some of the germplasm were chosen randomly from the Tri-State Breeding Program.

Stem cuttings, as a screening technique, also was chosen on purpose. The information from the literature indicated that black dot in the field does not consistently reduce potato yield $(28,45)$. As a result, the impact of black dot on potato and the amount of disease is commonly determined according to parameters of disease severity. The quantification of sclerotia on the roots and the stolons $(29,33,36,40)$, the quantification of colony forming units (CFU) in the crown and lower stem $(33,45)$, and the quantification of disease severity by stem cuttings $(28,33,45)$ are all valid approaches to determine black dot severity, and have been successfully utilized for field and greenhouse trials. However, in this study, sclerotia on the roots were not evaluated, as at the time of sampling they were not present on all selections; and CFU were not quantified since Stem cuttings, on the other hand, had in our opinion it is a cumbersome method.

demonstrated repetitive results in our field and greenhouse trials $(28,31)$ and were therefore chosen for this study.

The use of stem cuttings to evaluate black dot severity developed over time in our research program. In a 3-year field study, Nitzan (28) demonstrated the efficacy of the fungicide azoxystrobin to control black dot using stem cuttings. In another study, Nitzan et al. (31) cut stems every centimeter above the inoculation court and demonstrated the colonization pattern of potato stems by $C$. coccodes and its association to postbloom senescence. The later study (31) indicated that C. coccodes spreads up the stem from the inoculation court once the potato enters tuber bulking, which timewise is related to postbloom senescence. In addition, the fungus did not spread higher than $24 \mathrm{~cm}$ above the inoculation court.

Building on this knowledge, we decided in the present study to simplify the stem cutting evaluation technique. Instead of cutting segments every centimeter aboveground, stem segments were removed from

Table 1. Comparison of disease severity index (DSI) values among the industry standards in 2006, 2007, and 2008 field trials ${ }^{\mathrm{y}}$

\begin{tabular}{lccl}
\hline & \multicolumn{3}{c}{ DSI (\%) on aboveground stem $^{\mathbf{z}}$} \\
\cline { 2 - 4 } Standard cultivar & $\mathbf{2 0 0 6}$ & $\mathbf{2 0 0 7}$ & $\mathbf{2 0 0 8}$ \\
\hline Russet Burbank & $88 \mathrm{a}$ & $83 \mathrm{a}$ & $32 \mathrm{ab}$ \\
Ranger Russet & $88 \mathrm{a}$ & $44 \mathrm{~b}$ & $31 \mathrm{~b}$ \\
Umatilla Russet & $54 \mathrm{a}$ & $58 \mathrm{ab}$ & $69 \mathrm{a}$ \\
\hline
\end{tabular}

${ }^{y}$ Statistical analysis was carried out in SAS (Version 9.1; Cary, NC) using Proc Mixed at 5\% significance level. Different lowercase letters represent significant differences within a column.

${ }^{\mathrm{z}} \mathrm{DSI}=\left[\Sigma(\text { segment height in centimeters })^{*}(0\right.$ or 1$\left.)\right] /($ highest DSI value $)$, where segment heights were 2 and $6 \mathrm{~cm}$ in 2006, 2, 6, 10, and $14 \mathrm{~cm}$ in 2007, and 2, 6, and $10 \mathrm{~cm}$ in 2008; $0=$ noninfected segment and 1 = infected segment; and the max value of DSI was 8, 32, and 18 in 2006, 2007, and 2008, respectively.

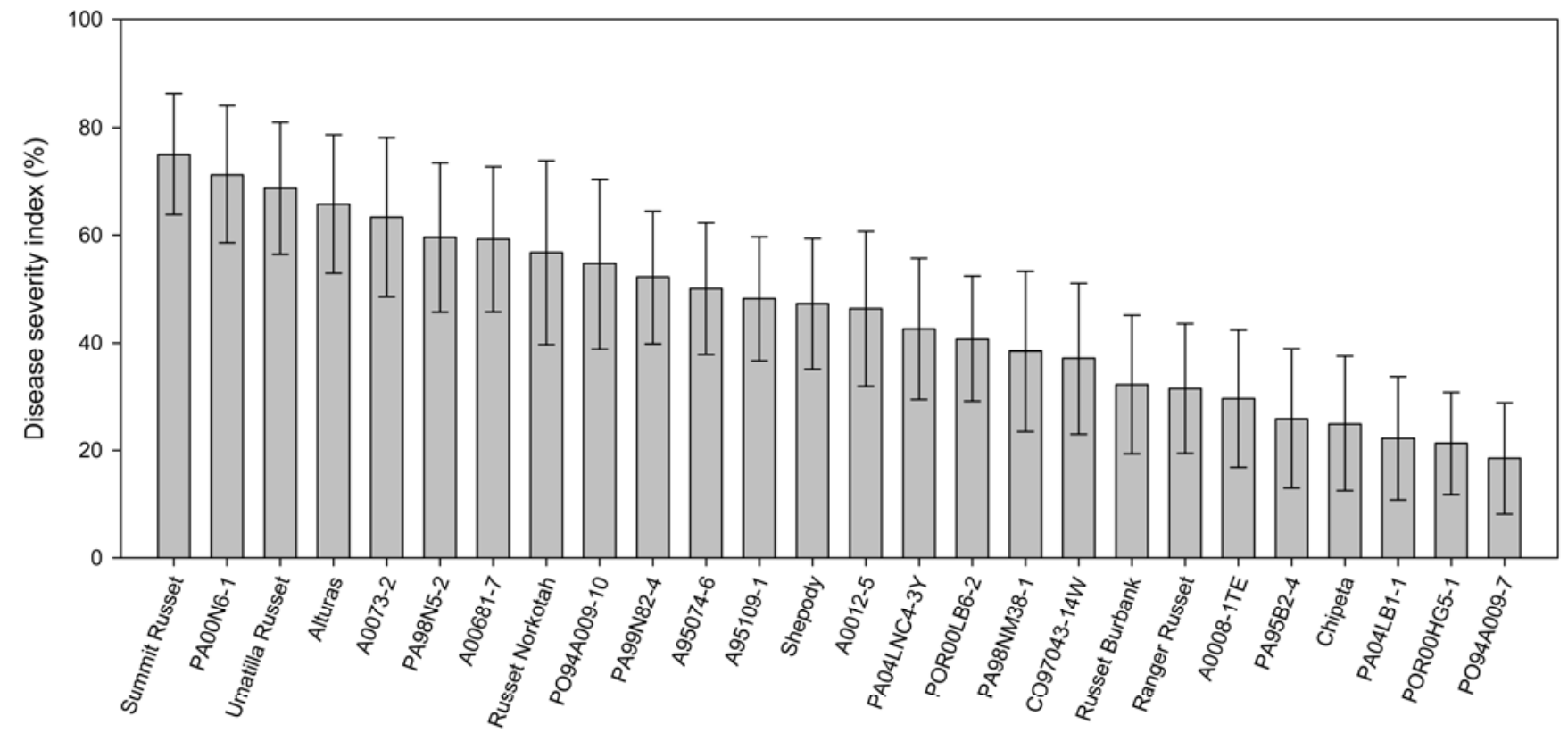

Potato selection

Fig. 3. Disease severity index (DSI) on aboveground stem of potato germplasm tested for black dot resistance in 2008 in a commercial potato field near Moses Lake, WA. Error bars represent the standard error of the mean. 
different heights using the soil level as a point of reference. Stem segments were removed from $2,6,10$, and $14 \mathrm{~cm}$ aboveground, which were heights that were chosen randomly to account for the distance. We did not sample above $14 \mathrm{~cm}$, however, because potato plants in the field at advanced stages of the season usually lie on the ground, and can get infected by $C$. coccodes at the point where the stem comes in contact with the soil. Yet our experience taught us that the first $20 \mathrm{~cm}$ of the stem aboveground stays erect and does not lie on the ground. To calculate disease severity with segments removed from different heights, a DSI was formulated that took into consideration both the colonization outcome (infected or not infected) and the height of the segment aboveground (2, 6,10 , and $14 \mathrm{~cm}$ ). This DSI fulfilled the need to test the hypothesis and demonstrated repetitive results over 3 years of field study.

Selecting a set of standard cultivars to serve as a susceptible baseline for comparisons was another consideration. For this purpose, the industry standard cultivars Russet Burbank, Ranger Russet, and Umatilla Russet were chosen due to their wide use by the potato industry in the $\mathrm{Pa}$ -

Table 2. Disease severity index (DSI) comparison and genetic stability evaluation for each potato selection in 2006, 2007, and 2008 field trials

\begin{tabular}{|c|c|c|c|c|c|c|c|}
\hline \multirow[b]{2}{*}{ Potato selection $^{z}$} & \multicolumn{3}{|c|}{ DSI comparison $(\%)^{\mathrm{w}}$} & \multicolumn{2}{|c|}{ Genetic stability $^{x}$} & \multicolumn{2}{|c|}{ Analyses interpretation ${ }^{y}$} \\
\hline & 2006 & 2007 & 2008 & $\sigma_{i}^{2}$ & $s_{i}^{2}$ & Genetic stability & DSI consistency \\
\hline A0012-5 & $38 \mathrm{a}$ & $32 \mathrm{a}$ & $46 \mathrm{a}$ & NS & NS & Stable & Consistent \\
\hline A00681-7 & $39 a$ & $41 \mathrm{a}$ & $59 \mathrm{a}$ & $<0.05$ & NS & $\mathrm{G} \times \mathrm{E}$ & Consistent \\
\hline A0073-2 & $21 \mathrm{~b}$ & $85 \mathrm{a}$ & $63 a$ & NS & NS & Stable & Not consistent \\
\hline A95109-1 & $38 \mathrm{~b}$ & $94 \mathrm{a}$ & $48 \mathrm{~b}$ & $<0.05$ & NS & $\mathrm{G} \times \mathrm{E}$ & Not consistent \\
\hline PA00N6-1 & $19 \mathrm{~b}$ & $68 \mathrm{a}$ & $71 \mathrm{a}$ & $<0.05$ & $<0.05$ & Unstable & Not consistent \\
\hline PA95B2-4 & $54 \mathrm{a}$ & $48 \mathrm{a}$ & $26 \mathrm{a}$ & NS & NS & Stable & Consistent \\
\hline PA98N5-2 & $64 \mathrm{a}$ & $83 \mathrm{a}$ & $60 \mathrm{a}$ & NS & NS & Stable & Consistent \\
\hline PA98NM38-1 & $25 \mathrm{a}$ & $46 \mathrm{a}$ & $38 \mathrm{a}$ & NS & NS & Stable & Consistent \\
\hline PO94A009-7 & $19 a$ & $55 \mathrm{a}$ & $19 \mathrm{a}$ & NS & NS & Stable & Consistent \\
\hline PA99N82-4 & $42 \mathrm{a}$ & $49 \mathrm{a}$ & $52 \mathrm{a}$ & NS & NS & Stable & Consistent \\
\hline POR00HG5-1 & $29 \mathrm{ab}$ & $61 \mathrm{a}$ & $21 \mathrm{~b}$ & NS & NS & Stable & Not consistent \\
\hline Summit Russet & $21 \mathrm{~b}$ & $42 \mathrm{~b}$ & $75 \mathrm{a}$ & $<0.05$ & $<0.05$ & Unstable & Not consistent \\
\hline Russet Norkotah & $35 \mathrm{~b}$ & $86 a$ & $57 \mathrm{ab}$ & NS & NS & Stable & Not consistent \\
\hline Shepody & $88 \mathrm{a}$ & $91 \mathrm{a}$ & $47 \mathrm{~b}$ & $<0.05$ & $<0.05$ & Unstable & Not consistent \\
\hline Russet Burbank & $88 \mathrm{a}$ & $83 \mathrm{a}$ & $32 \mathrm{~b}$ & $<0.05$ & NS & $\mathrm{G} \times \mathrm{E}$ & Not consistent \\
\hline Ranger Russet & $88 \mathrm{a}$ & $44 \mathrm{~b}$ & $31 \mathrm{~b}$ & $<0.05$ & $<0.05$ & Unstable & Not consistent \\
\hline Umatilla Russet & $54 \mathrm{a}$ & $58 \mathrm{a}$ & $69 \mathrm{a}$ & NS & NS & Stable & Consistent \\
\hline
\end{tabular}

${ }^{\mathrm{w}}$ Lowercase letters within a row represent statistical differences among years for each potato selection separately.

${ }^{\mathrm{x}} \sigma_{i}{ }^{2}=$ Stability variance components; $s_{i}{ }^{2}=$ variance not explainable by genotype or environment; NS = not significant.

${ }^{\mathrm{y}}$ Stable $=$ genotypes that were stable both before and after removal of environmental heterogeneity; Unstable $=$ genotypes that were unstable both before and after removal of environmental heterogeneity; $\mathrm{G} \times \mathrm{E}=$ genotypes in which DSI was unstable before removal of environmental heterogeneity but stable after removal of environmental heterogeneity; Consistent = lack of statistical differences among the DSI in 2006, 2007, or 2008.

${ }^{\mathrm{z}}$ List of 17 potato selections that were common to all three field trials. Boldface represents potato selections that were genetically stable and with consistent DSI.

Table 3. Comparison of disease severity index (DSI) values of each potato selection to the mean DSI of the industry standards Russet Burbank, Ranger Russet, and Umatilla Russet

\begin{tabular}{|c|c|c|c|c|c|c|c|c|c|c|c|c|}
\hline \multirow[b]{3}{*}{$\begin{array}{l}\text { Potato } \\
\text { selection }\end{array}$} & \multicolumn{3}{|c|}{2006} & \multicolumn{3}{|c|}{2007} & \multicolumn{3}{|c|}{2008} & \multicolumn{3}{|c|}{ Across all 3 years } \\
\hline & \multicolumn{3}{|c|}{ Mean DSI of standards $=76^{\mathrm{w}}$} & \multicolumn{3}{|c|}{ Mean DSI of standards $=62$} & \multicolumn{3}{|c|}{ Mean DSI of standards $=44$} & \multicolumn{3}{|c|}{ Mean DSI of standards $=61$} \\
\hline & $\begin{array}{c}\text { DSI of } \\
\text { selection }\end{array}$ & $\begin{array}{l}\text { DSI } \\
\text { est.y }\end{array}$ & $\begin{array}{l}\text { Resistance } \\
\text { rating }^{\mathrm{z}}\end{array}$ & $\begin{array}{c}\text { DSI of } \\
\text { selection }\end{array}$ & $\begin{array}{l}\text { DSI } \\
\text { est. }\end{array}$ & $\begin{array}{l}\text { Resistance } \\
\text { rating }\end{array}$ & $\begin{array}{c}\text { DSI of } \\
\text { selection }\end{array}$ & $\begin{array}{l}\text { DSI } \\
\text { est. }\end{array}$ & $\begin{array}{l}\text { Resistance } \\
\text { rating }\end{array}$ & $\begin{array}{c}\text { DSI of } \\
\text { selection }\end{array}$ & $\begin{array}{l}\text { DSI } \\
\text { est. }\end{array}$ & $\begin{array}{l}\text { Resistance } \\
\text { rating }\end{array}$ \\
\hline A0012-5 & 38 & -38 & $\mathrm{R}$ & 32 & -30 & $\mathrm{R}$ & 46 & +2 & $S$ & 39 & -22 & $\mathbf{R}$ \\
\hline A00681-7 & 39 & -37 & $\mathrm{R}$ & 41 & -21 & S & 59 & +15 & $\mathrm{~S}$ & 46 & -15 & MR \\
\hline A0073-2 & 21 & -55 & $\mathrm{R}$ & 85 & +23 & $\mathrm{~S}$ & 63 & +19 & $\mathrm{~S}$ & 56 & -5 & $\mathrm{~S}$ \\
\hline A95109-1 & 38 & -38 & $\mathrm{R}$ & 94 & +32 & $\mathrm{~S}$ & 48 & +4 & $\mathrm{~S}$ & 60 & -1 & $\mathrm{~S}$ \\
\hline PA00N6-1 & 19 & -57 & $\mathrm{R}$ & 68 & +6 & $\mathrm{~S}$ & 71 & +27 & $\mathrm{~S}$ & 53 & -8 & $\mathrm{~S}$ \\
\hline PA95B2-4 & 54 & -22 & $\mathrm{~S}$ & 48 & -14 & $\mathrm{~S}$ & 26 & -18 & $\mathrm{~S}$ & 43 & -18 & $\mathbf{R}$ \\
\hline PA98N5-2 & 64 & -12 & $\mathrm{~S}$ & 83 & +21 & $\mathrm{~S}$ & 60 & +16 & $\mathrm{~S}$ & 69 & +8 & $\mathrm{~S}$ \\
\hline PA98NM38-1 & 25 & -51 & $\mathrm{R}$ & 46 & -16 & $\mathrm{~S}$ & 38 & -6 & $\mathrm{~S}$ & 36 & -25 & $\mathbf{R}$ \\
\hline PO94A009-7 & 19 & -57 & $\mathrm{R}$ & 55 & -7 & $\mathrm{~S}$ & 19 & -25 & MR & 31 & -30 & $\mathbf{R}$ \\
\hline PA99N82-4 & 42 & -34 & $\mathrm{R}$ & 49 & -13 & $\mathrm{~S}$ & 52 & +8 & $\mathrm{~S}$ & 48 & -13 & $\mathrm{~S}$ \\
\hline PORO0HG5-1 & 29 & -47 & $\mathrm{R}$ & 61 & -1 & $\mathrm{~S}$ & 21 & -23 & MR & 37 & -24 & $\mathbf{R}$ \\
\hline $\begin{array}{r}\text { Summit } \\
\text { Russet }\end{array}$ & 21 & -55 & $\mathrm{R}$ & 42 & -20 & $S$ & 75 & +31 & $\mathrm{~S}$ & 46 & -15 & MR \\
\hline $\begin{array}{l}\text { Russet } \\
\text { Norkotah }\end{array}$ & 35 & -41 & $\mathrm{R}$ & 86 & +24 & $S$ & 57 & +13 & S & 59 & -2 & S \\
\hline Shepody & 88 & +12 & $S$ & 91 & +29 & S & 47 & +3 & S & 75 & +14 & $S$ \\
\hline
\end{tabular}

${ }^{\mathrm{w}}$ DSI $(\%)=$ Disease severity index on the aboveground stem; DSI $=[\Sigma$ (segment height in centimeters)*(0 or 1$\left.)\right] /($ highest DSI value), where segments heights were 2 and $6 \mathrm{~cm}$ in 2006, 2, 6, 10, and $14 \mathrm{~cm}$ in 2007, and 2,6, and $10 \mathrm{~cm}$ in 2008; $0=$ noncolonized segment and $1=$ colonized segment; and the highest values the DSI could obtain were 8, 32, and 18 in 2006, 2007, and 2008, respectively. Mean DSI of standards represent the average DSI rating for the industry standard cultivars Russet Burbank, Ranger Russet, and Umatilla Russet in 2006, 2007, 2008, and across all years.

${ }^{x}$ List of potato selections that were in common to all three field trials excluding the standard industry cultivars. Selections in boldface are resistant and moderately resistant germplasm.

${ }^{y}$ DSI estimate indicates the difference between the adjusted mean DSI of a chosen potato selection and the average DSI of the three industry standard cultivars (Russet Burbank, Ranger Russet, and Umatilla Russet) within a year and also across all years. A negative value indicates less disease. All values in this table are rounded numbers.

${ }^{\mathrm{z}} \mathrm{R}=$ Resistant to black dot, $\mathrm{MR}=$ moderately resistant to black dot, $\mathrm{S}=$ susceptible to black dot. 
cific Northwest United States (42). These cultivars were also documented in the greenhouse and the field to be affected by black dot, demonstrating high disease severities on stems and reduction of yield $(4,28,29,31,36)$. Identifying potato germplasm with less black dot than these industry standards would be a contribution to the industry, enhancing the future management of this disease, or breeding progress toward managing it with resistant cultivars.

An additional factor that was taken into consideration was the association between C. coccodes colonization of stems and plant maturity/postbloom senescence $(31,36)$. To standardize sampling time and limit this source of variation, which could affect disease severity levels, the stems were sampled each year postbloom during the senescence window. In the future, to enhance the efficiency of testing, our recommendations are to group different maturity categories into subtrials and include early maturing industry standards.

The analysis of black dot severity indicated a large genotype*environment interaction, an interaction characterized by inconsistent DSI levels and unstable genotypes even after removing environmental effects (Table 2). However, the genotype*environment interaction explained only $12 \%$ of the variation for DSI, whereas the largest source of variation (73\%) was unexplained by the model. Because of this, all future selections need to be tested several years in the field, and breeders should focus on genetically stable potato germplasm with consistent DSI levels for submission to variety trials and/or as parents in breeding programs. Pathologists will need to test the consistency of other disease severity evaluation methods and their adequacy in identifying resistance to black dot. Emerging from this is the novel information that Umatilla Russet is genetically stable and may be a more reliable standard for future breeding or screening than Russet Burbank and Ranger Russet (Table 2).

The results of the field screening indicated a graduated range of field resistance levels (Figs. 1 to 3 ) among the potato se- lections, suggesting that this trait is expressed in a continuous distribution, most likely a polygenic source of resistance. The broad-sense heritability for resistance to black dot was calculated to be 0.13 , which is low. The $95 \%$ confidence interval for this estimate was 0.00 to 0.68 . Such a broad confidence interval is indicative of the extreme variability for DSI and points out the difficulty of breeding for resistance to black dot. In this study, the potato selections, A0012-5, PA95B2-4, PA98NM38-1, PO94A009-7, and POR00HG5-1, demonstrated less black dot over 3 years than the three industry standard cultivars. A0012-5, PA95B2-4, PA98NM38-1, and PO94A0097 also demonstrated genetic stability and consistent DSI levels.

The pedigrees of the resistant potato selections A0012-5, PA95B2-4, PA98NM38-1, PO94A009-7, and POR00HG5-1, and the moderately resistant A00681-7 and Summit Russet, are presented in Table 4. The selections PA95B2-4, PA98NM38-1, PO94A009-7, and POR00HG5-1 possess resistance to the root galling stage of the powdery scab pathogen Spongospora subterranea f. sp. subterranea (30). They were derived from an introgression program to incorporate resistance to the Columbia root-knot nematode $M$. chitwoodi from the Mexican wild species Solanum bulbocastanum (6); and PA95B2-4, PA98NM38-1, and PO94A009-7 also have the commercial cultivar Summit Russet appearing in multiple generations in their ancestry (Table 4) (6). The potato selection POR00HG5-1 is a backcross introgressant of an initial cross with the wild species Solanum hougasii.

Achieving management of black dot is challenging. The disease is multifaceted and can initiate from seed-tuber and soilborne inoculum $(10,28,29,31-36,44-46)$, and it affects plant health, yield, and tuber quality. To date, with the ban on methyl bromide, soil fumigants are not available that can economically control the soilborne inoculum of the fungus (D. A. Johnson and D. L. Batchelor, unpublished data); and seed treatments are not available that can control the internal seed-tuber-borne inoculum $(28,38)$. This leaves limited man- agement options with fungicides $(9,26,28)$. Black dot can be reduced during the growing season with strobilurin-based fungicides $(9,28)$. However, their application is expensive, and resistance to them has been documented in Alternaria spp. (25,37), suggesting the risk of resistance buildup in populations of $C$. coccodes. Rotations with crops that are not hosts for C. coccodes, such as wheat, barley, maize, or peas $(7,34)$, are possible but not economically justifiable in the Columbia Basin of Washington State and Oregon since the sclerotia of $C$. coccodes can survive in the soil up to 8 years (13). Under these conditions, potato cultivars with genetic resistance to black dot seem to be a good economical and sustainable option.

In conclusion, this study reports novel information regarding the identification of black dot resistant potato germplasm. Emerging from this study are: (i) an innovative approach to quantifying black dot severity on potato stems; (ii) the important information regarding genetic stability of potato germplasm in relation to black dot severity; and (iii) the establishment of Umatilla Russet as a reliable standard cultivar for comparisons. This study is only a first step toward the development of potato varieties with resistance to black dot. Yet it is a milestone since it identified potato germplasm with a dual genetic resistance to both potato black dot, caused by $C$. coccodes, and powdery scab, caused by $S$. subterranea. These germplasm are promising steps toward the development of future potato cultivars with a combined resistance to two major soilborne diseases of potato.

\section{ACKNOWLEDGMENTS}

This research was supported by the Washington State Potato Commission. We thank Mr. Richard A Quick and Mrs. Ricarda Castanieda for their technical support.

\section{LITERATURE CITED}

1. Agrios, G. N. 1998. Plant Pathology, 3rd ed. Academic Press, New York. p. 782.

2. Andrivon, D., Lucas, J. M., Guérin, C., and Jouan, B. 1998. Colonization of roots, stolons, tubers and stems of various potato (Solanum tuberosum) cultivars by the black-dot fungus $\mathrm{Col}$ letotrichum coccodes. Plant Pathol. 47:440-445.

3. Andrivon, D., Ramage, K., Guerin, C., Lucas, J. M., and Jouan, B. 1997. Distribution and

Table 4. Pedigree of potato selections that were tested in the field from 2006 to 2008 and were more resistant to black dot than the industry standard cultivars Russet Burbank, Ranger Russet, and Umatilla Russet

\begin{tabular}{ll}
\hline Potato selection & Pedigree $^{\mathbf{z}}$ \\
\hline A0012-5 & GemStar Russet $\times$ Wallowa Russet \\
PA95B2-4 & $(((($ S. $b l b+R 4) \times$ Summit Russet $)) \times$ Summit Russet $) .86 \times$ Lemhi Russet $) \times$ A8259-5 \\
PA98NM38-1 & $(((($. $b l b+$ R4 $) \times$ Summit Russet $)) \times$ Summit Russet $) 89 \times$ Lemhi Russet $) \times$ Summit Russet \\
PO94A009-7 & $((($ S. $b l b+$ R4 $) \times$ Summit Russet $)) \times$ Summit Russet $) .51 \times$ Ranger Russet \\
A00681-7 & Western Russet $\times$ PA92A08-17 \\
Summit Russet & A77236-6 TND329-1Russ \\
\hline
\end{tabular}

${ }^{2}$ S. blb = Solanum bulbocastanum; $S$. blb $+\mathrm{R} 4=$ Initial $\mathrm{F}_{1}$ was a somatic hybrid between SB22 and R4, a tetraploid S. tuberosum breeding line. GemStar Russet, Wallowa Russet, Summit Russet, Lemhi Russet, and Ranger Russet are russet skin varieties, and A8259-5, A89875-5, and PA92A08-17 are russet skin breeding lines. These potato varieties were developed and named in the Northwest Tri-State potato breeding and variety development program, which is a collaborative effort of the USDA-ARS, Oregon State University, Washington State University, and University of Idaho, each state's potato commission and industry representatives, aimed to developing potatoes with agronomic, horticultural, and pathological traits suitable and sought for by the potato industry in the Pacific Northwest United States. 
fungicide sensitivity of Colletotrichum coccodes in French potato-producing areas. Plant Pathol. 46:722-728.

4. Aqeel, A. M., Pasche, J. S., and Gudmestad, N. C. 2008. Variability in morphology and aggressiveness among North American vegetative compatibility groups of Colletotrichum coccodes. Phytopathology 98:901-909.

5. Barkdoll, A. W., and Davis, J. R. 1992. Distribution of Colletotrichum coccodes in Idaho and variation in pathogenicity on potato. Plant Dis. 76:131-135.

6. Brown, C. R., Mojtahedi, H., James, S., Novy, R. G., and Love, S. 2006. Development and evaluation of potato breeding lines with introgressed resistance to Columbia root-knot nematode (Meloidogyne chitwoodi). Am. J. Potato Res. 83:1-8.

7. Celetti, M. J. 1990. A note on the incidence of soil-borne fungi in six crops used in rotation with potatoes. Phytoprotection 71:97-100.

8. Chesters, C. G. C., and Hornby, D. 1965. Studies on Colletotrichum coccodes. I. The taxonomic significance of variation in isolates from tomato roots. Trans. Br. Mycol. Soc. 48:573-581.

9. Cummings, T. F., and Johnson, D. A. 2008. Effectiveness of early season, single application of azoxystrobin for the control of potato black dot as evaluated by three assessment methods. Am. J. Potato Res. 85:422-431.

10. Dashwood, E. P., Fox, R. A., and Perry, D. A. 1992. Effect of inoculum source on root and tuber infection by potato blemish disease fungi. Plant Pathol. 41:215-223.

11. Denner, F. D. N., Millard, C., Geldenhuys, A., and Wehner, F. C. 1997. Treatment of seed potatoes with Prochloraz for simultaneous control of silver scurf and black dot on progeny tubers. Potato Res. 40:221-227.

12. Denner, F. D. N., Millard, C. P., and Wehner, F. C. 1998. The effect of seed- and soil-borne inoculum of Colletotrichum coccodes on the incidence of black dot on potato. Potato Res. 41:51-56.

13. Dillard, H. R., and Cobb, A. C. 1998. Survival of Colletotrichum coccodes in infected tomato tissue and in soil. Plant Dis. 82:235-238.

14. Ducomet, V. 1908. Une nouvelle maladie de la pomme de terrre: la 'dartose'. Ann. Ecole Nat. Agric. Rennes 2:24-47.

15. Heilmann, L. J., Nitzan, N., Johnson, D. A., Pasche, J. S., Doetkott, C., and Gudmestad, N. C. 2006. Genetic variability in the potato pathogen Colletotrichum coccodes as determined by amplified fragment length polymorphism and vegetative compatibility group analyses. Phytopathology 96:1097-1107.

16. Jeger, M. J., Hide, G. A., Van den Boogert, P. H. J. F., Termorshuizen, A. J., and Van Baarlen, P. 1996. Pathology and control of soil-borne fungal pathogens of potato. Potato Res. 39:437-469.

17. Johnson, D. A. 1994. Effect of foliar infection by Colletotrichum coccodes on yield of russet Burbank potato. Plant Dis. 78:1075-1078

18. Johnson, D. A., and Miliczky, E. R. 1993. Effects of wounding and wetting duration on infection of potato foliage by Colletotrichum coccodes. Plant Dis. 77:13-17.

19. Johnson, D. A., and Miliczky, E. R. 1993. Distribution and development of black dot, Verticillium wilt, and powdery scab on Russet Burbank potatoes in Washington State. Plant Dis. 77:74-79.

20. Johnson, D. A., Rowe, R. C., and Cummings, T. F. 1997. Incidence of Colletotrichum coccodes certified potato seed tubers planted in Washington State. Plant Dis. 81:1199-1202.

21. Kang, M. S. 1989. A new SAS program for calculating stability-variance parameters. J. Hered. 80:415.

22. Knapp, S. J., Stroup, W. W., and Ross, W. M. 1985. Exact confidence intervals for heritability on a progeny mean basis. Crop Sci. 25:192194.

23. Komm, D. A., and Stevenson, W. R. 1978. Tuber-borne infection of Solanum tuberosum 'superior' by Colletotrichum coccodes. Plant Dis. Rep. 62:682-687.

24. Lees, A. K., and Hilton, A. J. 2003. Black dot (Colletotrichum coccodes): An increasingly important disease of potato. Plant Pathol. 52:312.

25. Ma, Z., Felts, D., and Michailides, T. J. 2003. Resistance to azoxystrobin in Alternaria isolates from pistachio in California. Pestic. Biochem. Physiol. 77:66-74.

26. Marais, L. 1990. Efficacy of fungicides against Colletotrichum coccodes on potato tubers. Potato Res. 33:275-281.

27. Miller, J. S., and Hopkins, B. G. 2008. Checklist of a holistic potato health management plan. Potato Health Management, 2nd ed. D. A. Johnson, ed. American Phytopathological Society, St. Paul, MN.

28. Nitzan, N., Cummings, T. F., and Johnson, D. A. 2005. Effect of seed-tuber generation, soilborne inoculum, and azoxystrobin application on development of potato black dot caused by Colletotrichum coccodes. Plant Dis. 89:11811185

29. Nitzan, N., Cummings, T. F., and Johnson, D. A. 2008. Disease potential of soil- and tuberborne inocula of Colletotrichum coccodes and black dot severity on potato. Plant Dis. 92:1497-1502.

30. Nitzan, N., Cummings, T.F ., Johnson, D. A., Miller, J. S., Batchelor, D. L., Olsen, C., Quick, R. A., and Brown, C. R. 2008. Resistance to root galling caused by the powdery scab pathogen Spongospora subterranea in potato. Plant Dis. 92:1643-1649.

31. Nitzan, N., Evans, M., and Johnson, D. A. 2006. Colonization of potato plants after aerial infection by Colletotrichum coccodes, causal agent of potato black dot. Plant Dis. 90:9991003.

32. Nitzan, N., Hamm, P., Johnson, D., Miller, J., and David, N. 2005. Bumpy tuber - a post harvest disease on potato associated with the black dot fungus. Washington State Potato Progress 5(15):1-6. Washington State Potato Commission. (Online) www.potatoes.com.

33. Nitzan, N., Hazanovsky, M., Tal, M., and Tsror (Lahkim), L. 2002. Vegetative compatibility groups in Colletotrichum coccodes, the causa agent of black dot on potato. Phytopathology 92:827-832.

34. Nitzan, N., Lucas, B. S., and Christ, B. J. 2006. Colonization of rotation crops and weeds by the potato black dot pathogen Colletotrichum coccodes. Am. J. Potato Res. $83: 503-507$

35. Nitzan, N., and Tsror (Lahkim), L. 2003. Effect of temperature and $\mathrm{pH}$ on in vitro growth rate and sclerotia density of Colletotrichum coccodes isolates from different VCGs. Am. J. Potato Res. 80:335-339.

36. Nitzan, N., Tsror (Lahkim), L., and Johnson, D. A., 2006. Vegetative compatibility groups and aggressiveness of North American isolates of Colletotrichum coccodes, the causal agent of potato black-dot. Plant Dis. 90:1287-1292.

37. Pasche, J. S., Wharam, C. M., and Gudmestad, N. C. 2004. Shift in sensitivity of Alternaria solani in response to QoI fungicides. Plant Dis. 88:181-187.

38. Powelson, M. L., and Rowe, R. C. 2008. Managing diseases caused by seed-borne and soilborne fungi and fungus-like pathogens. Potato Health Management, 2nd ed. D. A. Johnson, ed. American Phytopathological Society, St. Paul, MN.

39. Read, P. J. 1991. The susceptibility of tubers of potato cultivars to black dot (Colletotrichum coccodes (Wallr.) Hughes). Ann. Appl. Biol. 119:475-482.

40. Read, P. J., and Hide, G. A. 1988. Effect of inoculum source and irrigation on black dot disease of potato (Colletotrichum coccodes (Wallr.) Hughes) and its development during storage. Potato Res. 31:493-500.

41. Read, P. J., and Hide, G. A. 1995. Development of black dot disease (Colletotrichum coccodes (Wallr.) Hughes) and its effect on the growth and yield of potato plants. Ann. Appl. Biol. 127:57-72.

42. Schreiber, A. 2006. Potato tuber-worm: A potential new pest of potato in Washington's storages. Potato Progress 6(13):3. Washington State Potato Commission. (Online) www.potatoes.com.

43. Shukla, G. K. 1972. Some statistical aspects of partitioning genotype-environment components of variability. Heredity 29:237-245.

44. Tsror (Lahkim), L., Aharon, M., and Erlich, O. 1999. Survey of bacterial and fungal seedborne diseases in imported and domestic poato seed tubers. Phytoparasitica 27:1-12.

45. Tsror (Lahkim), L., Erlich, O., and Hazanovsky, M. 1999. Effect of Colletotrichum coccodes on potato yield, tuber quality, and stem colonization during spring and autumn. Plant Dis. 83:561-565.

46. Tsror (Lahkim), L., and Johnson, D. A. 2000. Colletotrichum coccodes on potato. Pages 362 373 in: Colletotrichum - Host specificity, pathology and host-pathogen interaction. D Prusky, S. Freeman, and M. B. Dickman, eds. American Phytopathological Society, St Paul, MN.

47. Zar, J. H. 1996. Biostatistical Analysis, 3rd ed Prentice Hall, Upper Saddle River, NJ. 